\title{
Studies on the effect of unilateral and bilateral castration on plasma testosterone and LH levels in the bull
}

\author{
N. B. Haynes, H. D. Hafs,${ }^{*}$ K. Purvis $†$ and J. G. Manns $\ddagger$ \\ Department of Physiology and Environmental Studies, University of Nottingham \\ School of Agriculture, Sutton Bonington, Loughborough LE12 5RD, Leicestershire, U.K.
}

As part of a study on pituitary-testicular feedback mechanisms, the plasma hormone levels of 9 Friesian bulls, 6-8 months old, were examined at the time of unilateral castration. Blood (10 ml) was taken from indwelling jugular cannulae at $30 \mathrm{~min}$ intervals for $48 \mathrm{hr}$, a testis being removed under local anaesthesia (Lignocaine, Pharmaceutical Man. Co.) from each animal after $24 \mathrm{hr}$. Testosterone concentrations in plasma were measured by the radioimmunoassay method of Haynes, Hafs, Waters, Manns \& Riley (1975) and LH concentrations by the radioimmunological procedure described by Oxender, Hafs \& Edgerton (1972). One bull had no detectable testosterone after unilateral castration and was not included in the analysis.

Table 1. Effect of unilateral castration on plasma testosterone and LH in 8 bulls, 6-8 months old

\begin{tabular}{|c|c|c|c|c|}
\hline Parameter & $\begin{array}{c}\text { Before } \\
\text { castration }\end{array}$ & $\begin{array}{c}\text { After } \\
\text { castration }\end{array}$ & S.E.D.* & Significance \\
\hline No. of testosterone peaks & 41 & 33 & & \\
\hline No. of LH peaks & 47 & 48 & & \\
\hline Mean testosterone peak height $(\mathrm{ng} / \mathrm{mI})$ & $7 \cdot 02$ & $3 \cdot 78$ & 0.85 & $P<0.01$ \\
\hline Variance $\dagger$ & $4 \cdot 29$ & 0.69 & & $P<0.001$ \\
\hline Mean LH peak height (ng/ml) & $1 \cdot 59$ & 1.91 & $0 \cdot 17$ & N.S. \\
\hline Variance & 0.41 & $1 \cdot 04$ & & $P<0.05$ \\
\hline Mean interval between testosterone peaks (hr) & $4 \cdot 8$ & $5 \cdot 3$ & 0.46 & N.S. \\
\hline Variance ${ }^{\dagger}$ & $2 \cdot 92$ & $0 \cdot 30$ & & $P<0.001$ \\
\hline Mean interval between $\mathrm{LH}$ peaks (hr) & $3 \cdot 71$ & $3 \cdot 68$ & 0.63 & N.S. \\
\hline Variance $†$ & $4 \cdot 7$ & $2 \cdot 9$ & & N.S. \\
\hline
\end{tabular}

* Standard error of the difference between means based on between animal error from a two-way ANOVAR with unequal replication.

$\dagger$ Within animal variation $(<25$ degrees of freedom).

A summary of the results for 8 animals is given in Table 1. Hormone concentrations before castration were in accord with previous observations in the bull (Katongole, Naftolin \& Short, 1971; Smith, Mongkonpunya, Hafs, Convey \& Oxender, 1973; Haynes et al., 1975). Plasma testosterone levels were equivalent to those found in post-pubertal animals, although the animals had not reached puberty as indicated by the lack of complete spermatogenesis. Levels of the hormone fluctuated markedly during a $24 \mathrm{hr}$ period but the fluctuations were irregular and did not conform to particular patterns. Testosterone surges were in general preceded by peaks in plasma $\mathrm{LH}$ but the irregularity of testosterone secretion made interpretation of data in regard to pituitary-testicular feedback mechanisms difficult. In the present study there was no detectable difference in the LH concentrations before and after castration, suggesting that levels were unaffected by surgical stress. This lack of change contrasted with a significant fall in peak plasma testosterone and a reduction in the numbers of peaks after unilateral castration. It appears, therefore that short-term negative-feedback effects

* Present address: Animal Reproduction Laboratory, Department of Dairy Science, Michigan State University, East Lansing, Michigan 48823, U.S.A.

$\dagger$ Present address: Swedish Medical Research Council, Reproductive Endocrinology Research Unit, Karolinska Sjokhuset, 10401 Stockholm 60, Sweden.

$¥$ Present address: Department of Veterinary and Physiological Sciences, University of Saskatchewan, Saskatoon, Canada. 
upon LH are not closely related to particular levels of plasma testosterone. This was further supported by the observation that several LH peaks occurred at times when plasma testosterone levels were high.

The peaks of testosterone concentrations appeared much more regular after unilateral castration and this impression was confirmed by the significant reductions in the variances of peak height and peak interval (Table 1). The symmetry of the testosterone peaks was also greater after unilateral castration and the 'twinning' of peaks which often occurs in the normal animal was less frequent. The temporal relationships between $\mathbf{L H}$ and testosterone levels were much clearer after unilateral castration and such animals could be more useful models than intact animals for the study of testispituitary relationships. The present findings suggest that the two testes may not secrete testosterone in synchrony and that they are, to some extent, independent entities. This possibility is being investigated further.

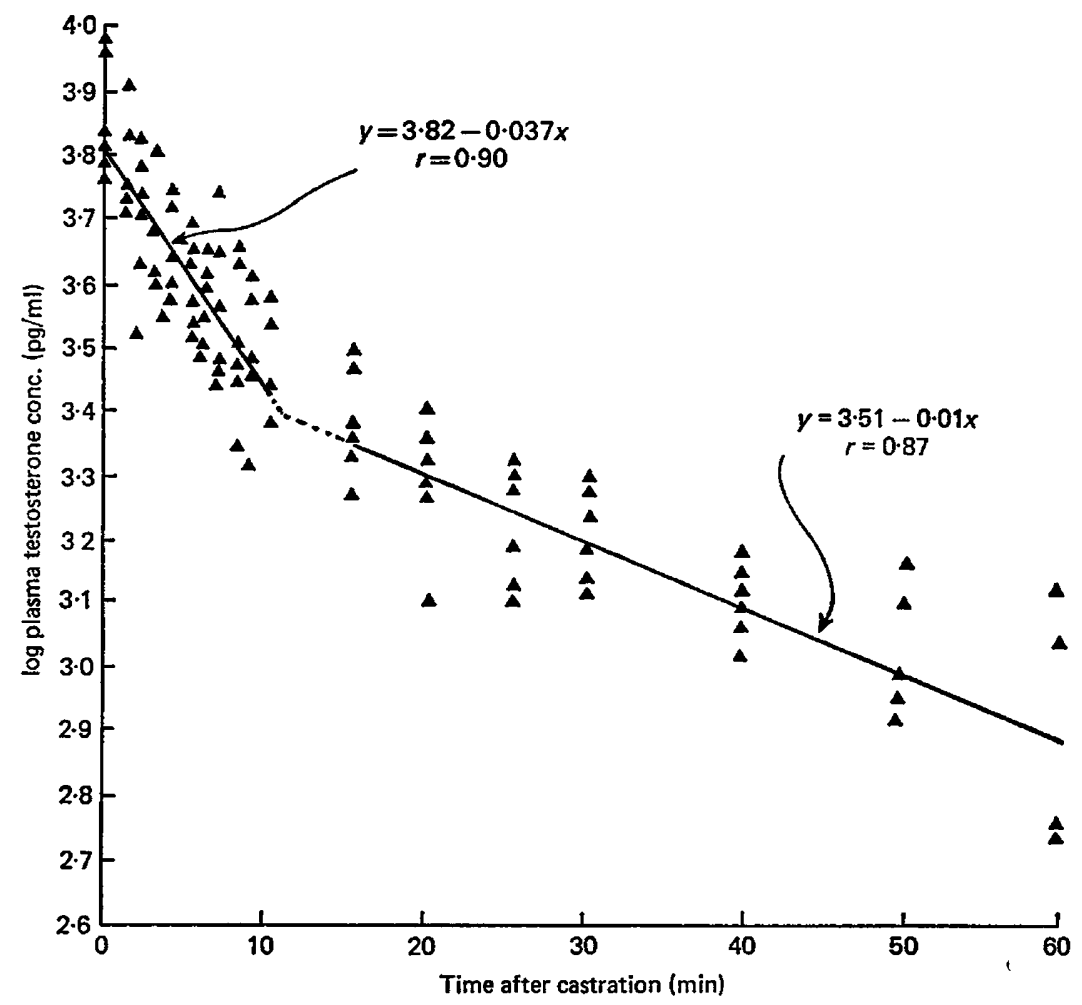

Text-fig. 1. The disappearance of plasma testosterone after removal of the remaining testis from 6 unilaterally castrated prepubertal bulls.

The second testis was removed from these animals 60 days after unilateral castration and 6 of the bulls were used to examine the half-life of plasma testosterone. They were injected i.m. with $500 \mu \mathrm{g} \mathrm{LH}-\mathrm{RH}$ (Hoechst Pharmaceuticals Ltd) $1 \mathrm{hr}$ before removal of the second testis to ensure high testosterone levels (Mongkonpunya, Hafs, Convey, Tucker \& Oxender, 1975). The testis was removed under local anaesthesia and jugular blood samples $(10 \mathrm{ml})$ were withdrawn at 1 -min intervals until $10 \mathrm{~min}$, at 5-min intervals until $30 \mathrm{~min}$, and at 10-min intervals until $60 \mathrm{~min}$ after castration. Testosterone levels were measured in each plasma sample by the method of Haynes et al. (1975). The disappearance of testosterone in plasma could not be described by a single exponential and is therefore represented by two curves as shown in Text-fig. 1. The initial disappearance curve, presumably representing circulating testosterone, had a mean half-life of $8 \mathrm{~min}$ and the final curve rep- 
resenting depot hormone a half-life of $30 \mathrm{~min}$. These values are similar to the 7 and $34 \mathrm{~min}$, respectively, reported for man (Horton, Shinsako \& Forsham, 1965).

We thank Mr H. L. Back for advice on statistics, Mr R. J. Waters, M.R.C.v.S., for skilled assistance during this work, Mr Julian Best (Hoechst) for providing LH-RH and the U.S. National Institutes of Health for supplying NIH-LH-B9.

\section{References}

Haynes, N.B., Hafs, H.D., Waters, R.J., Manns, J.G. \& RiLeY, A. (1975) Stimulatory effect of prostaglandin $F_{2 \alpha}$ on the plasma concentration of testosterone in bulls. $J$. Endocr. 66, 329-338.

Horton, R., Shinsako, J. \& Forsham, P.H. (1965) Testosterone production and metabolic clearance rates with volumes of distribution in normal adult men and women. Acta endocr., Copenh. 48, 446458.

Katongole, C.B., Naftolin, F. \& Short, R.V. (1971) Relationship between blood levels of luteinizing hormone and testosterone in bulls and the effects of sexual stimulation. J. Endocr. 50, 457-466.
Mongkonpunya, K., Hafs, H.D., Convey, E.M., TUCKeR, H.A. \& OXeNDER, W.D. (1975) Serum luteinizing hormone, testosterone and androstenedione in pubertal and prepubertal bulls after gonadotrophin releasing hormone. J. Anim. Sci. 40, 682-686.

OXENDER, W.D., HAFS, H.D. \& EDGerTON, L.A. (1972) Serum growth hormone, $\mathbf{L H}$ and prolactin in the pregnant cow. J. Anim. Sci. 35, 51-55.

Smith, O.W., MongkonPunya, K., HaFs, H.D., CONVEY, E.M. \& OXender, W.D. (1973) Blood serum testosterone after sexual preparation or ejaculation, or after injections of $\mathrm{LH}$ or prolactin in bulls. J. Anim. Sci. 37, 979-984.

Received 3 September 1975 